\title{
ЕЛЕМЕНТИ МАРКЕТИНГОВОГО МЕХАНІЗМУ
}

\section{Коноваленко А.С., канд. екон. наук, доцент}

\section{Таврійський державний агротехнологічний університет імені Дмитра}

\section{Моторного}

Постановка проблеми. Необхідність вирішення основних проблем сталого розвитку вимагає пошуку нових підходів до встановлення балансу між задоволенням сучасних потреб людства та захистом інтересів майбутніх поколінь, включаючи їх потребу в безпечному і здоровому довкіллі. Такому спрямуванню відповідає актуальна концепція соціально-етичного маркетингу, ефективність та затребуваність якого доведена поширенням популярності його впровадження виробниками в усьому світі. Доцільним $\epsilon$ дослідження можливостей застосування потенціалу маркетингового механізму задля вирішення актуальних проблем суспільства. 3 огляду на його складність та цілісність, маркетинговий механізм слід розглядати як відкриту систему, що містить певні складові. Визначення структури маркетингового механізму впливає на формування наукового підгрунтя для розуміння принципів та закономірностей його функціонування, які прямо впливають на ефективність його застосування при вирішення важливих проблем суспільства.

Аналіз останніх досліджень i публікацій. Аналіз наукових робіт українських дослідників доводить, що поняття «маркетинговий механізм» широко застосовується науковцями у різному контексті. Розгляд маркетингового механізму як системи здійснено Квасницькою Р.С. та Джерелейко С.О., які у його складі зазначають послідовність процесів або порядок виконання відповідних робіт [1, с. 67]. У структурі механізму Смирнов С. О. та Гільорме Т. В. виокремлюють системи цілей, місій, принципів, функцій, моделей, методів, який включає підсистеми. Вони підкреслюють, що функціонування механізму засновується на постійній взаємодії елементів, що спрямована на конкретні критерії успішності управлінських рішень [2, с. 313]. У своїх дослідженнях Гуляєв В.В. дійшов висновку, що механізму як системі, притаманні наявність «входу», що передбачає вхід енергії одного виду, та «виходу», що передбачає отримання енергії, руху або коливання іншого виду, а механізм перетворює рух енергії [3, c. 57]. Ілляшенко С.М. зазначає, що механізм забезпечує послідовний розвиток об'єкту, а структура та зміст механізму змінюються у процесі розвитку суспільного виробництва [4, с. 376]. У роботах Рудницького С.В. простежується думка, що дії та зв'язки не є елементами механізму, а характеризують сутність зв'язків між елементами механізму [5]. На необхідності досліджувати окремі елементи, взаємозв'язки між ними, стан механізму та його динаміку, функції, дисфункції та причини таких дисфункцій наголошують Заславська T.I. та Ривкіна Р.В. [6, с. 96]. В роботах Дороніної М.С. зазначено, що функціонування механізму базується на його суттєвій ознаці: наявність певної послідовності та 
ланцюгової реакції взаємодії його окремих елементів [7, с. 128]. Колодій А.М. та Олійник А.Ю. стверджують, що кожен механізм є високоорганізованою системою з єдністю елементів [8, с. 219].

Невирішені складові загальної проблеми. Існують певні напрацювання науковців у питаннях трактування поняття «маркетинговий механізм», однак досі не сформований однозначний підхід до визначення його ключових елементів та складників.

Формулювання цілей статті. Метою статті $є$ визначення ключових елементів маркетингового механізму шляхом узагальнення наукових підходів та поглядів дослідників на структуру маркетингового механізму на основі контент-аналізу наукових робіт.

Виклад основного матеріалу дослідження. Системний підхід до визначення змісту маркетингового механізму, який $\epsilon$ популярним серед науковців, дозволяє стверджувати про наявність у структурі маркетингового механізму як у відкритій системі таких ключових характеристик, як «вхід», «вихід» та безпосередньо внутрішня будова механізму, що містить структурні елементи. На основі обгрунтованого визначення змісту категорії «маркетинговий механізм» серед його структурних елементів зазначаємо наступні складові: суб'єкти маркетингу, взаємозв'язки між ними, важелі впливу, об'єкт впливу, наявність якого обумовлена цільовою метою, суб'єкт, що керує станом маркетингового механізму та забезпечує його стійкість (табл. $1)$.

Таблиия 1

\section{Структурні елементи маркетингового механізму}

\begin{tabular}{|c|c|c|}
\hline \multicolumn{2}{|c|}{ Елемент системи } & Характеристика \\
\hline \multicolumn{2}{|l|}{ Вхід } & $\begin{array}{l}\text { Потрапляння енергії, ресурсів (матеріальних, інформаційних тощо), } \\
\text { стан об’єкту впливу одного виду до маркетингового механізму }\end{array}$ \\
\hline \multirow{6}{*}{ 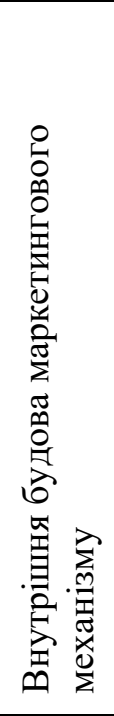 } & $\begin{array}{l}\text { Суб’єкти } \\
\text { маркетингу }\end{array}$ & $\begin{array}{l}\text { Держава, державні органи влади, виробники, посередники, } \\
\text { конкуренти, споживачі, маркетингові агенти тощо. }\end{array}$ \\
\hline & Об’єкти впливу & $\begin{array}{l}\text { Те, що піддається зміні, на що спрямоване функціонування } \\
\text { маркетингового механізму та важелі суб’єктів маркетингу. Об’єкт } \\
\text { обумовлений цільовою метою маркетингового механізму }\end{array}$ \\
\hline & Важелі впливу & $\begin{array}{l}\text { Специфічні маркетингові інструменти, які використовують суб’єкти } \\
\text { маркетингу як важелі впливу на інших суб'єктів маркетингу та об'єкт } \\
\text { впливу }\end{array}$ \\
\hline & $\begin{array}{l}\text { Взаємозв'язки } \\
\text { між суб'єктами } \\
\text { маркетингу }\end{array}$ & $\begin{array}{l}\text { Взаємодія суб’єктів маркетингу, що призводить до ланцюгової реакції } \\
\text { між ними та послідовній, поступовій зміні об'єкту впливу }\end{array}$ \\
\hline & Цільова мета & Очікуваний результат зміни об’єкту впливу \\
\hline & $\begin{array}{l}\text { Суб’єкт } \\
\text { управління }\end{array}$ & $\begin{array}{l}\text { Суб’єкт, що керує станом маркетингового механізму, встановлює } \\
\text { обмеження для функціонування та повноважень суб’єктів маркетингу, } \\
\text { забезпечує стійкість маркетингового механізму та його адаптивність } \\
\text { до змін у зовнішньому середовищі }\end{array}$ \\
\hline \multicolumn{2}{|l|}{ Вихід } & $\begin{array}{l}\text { Отримання енергії, ресурсу, стану об’єкту впливу у перетвореному } \\
\text { вигляді (стані), зміна якого відбулась під впливом функціонування } \\
\text { маркетингового механізму }\end{array}$ \\
\hline
\end{tabular}

Джерело: складено автором 
Попередні дослідження автора дозволили сформулювати узагальнений підхід до трактування поняття маркетингового механізму як стійкої керованої систему взаємодії суб'єктів маркетингу, які використовують відповідні важелі та маркетинговий інструментарій у їх ланцюговій реакції задля досягнення цільової мети (цільового результату). Застосування суб'єктами маркетингу специфічних маркетингових інструментів з метою оптимізації процесів та явищ $\epsilon$ важливою ознакою функціонування механізму саме маркетингової природи. Так, у своїх роботах Старостіна А.О. стверджує, що маркетинг покликаний вивчати попит та вимоги ринку та враховувати отриману інформацію для обгрунтування стратегії діяльності підприємств [9, с. 41]. До спеціальних інструментів маркетингу відносять комплекс інструментів маркетинг-міксу. Однак, на нашу думку, найважливішим елементом маркетингового механізму, який обумовлює доцільність його функціонування, виправданість перетворення об'єкту впливу та застосування відповідних важелів суб'єктами маркетингу, є наявність та характер тієї чи іншої цільової мети. Специфіка очікуваного результату обумовлюе визначення характеристик складових елементів маркетингового механізму. Наприклад, низка робіт науковців присвячені дослідженням специфіки застосування маркетингового механізму у сфері державного управління, розвитку територій, активізації господарської діяльності окремих галузей, вирішення певних соціальних проблем суспільства тощо. Це свідчить широкі можливості застосування наукових підходів маркетингового механізму для виконання конкретних практичних завдань. Цільовий характер функціонування маркетингового механізму зазначено у роботах Братенкової Т.М. [10, с. 242] та Курбацької Л.М. [11, с. 22], що підтверджують потенціал застосування маркетингового механізму для досягнення встановленою мети. Розглядаючи роль суб'єкту управління станом маркетингового механізму слід зазначити, що певні механізми виникають природньо як механізм саморегулювання та самоорганізації, а деякі механізми - створюють свідомо. Самоорганізаційні процеси, як правило, виникають історично першими. При цьому, на думку Рудницького С., механізми самоорганізації складніше піддаються подальшому регулюванню [5].

Таким чином, зазначені складові маркетингового механізму слугують теоретичним базисом для дослідників та розробників, які на основі специфіки очікуваного ефекту (мети) мають адаптувати та деталізувати складові маркетингового механізму. Доцільність такого підходу підтверджує позиція Дороніної М.С., яка розглядає маркетинговий механізм як відкриту систему та стверджує, розробник має визначати у механізмі такі елементи, які на виході забезпечать бажані значення істотних параметрів при мінімальних витратах. [7, с. 128]. Висновки 3 проведеного дослідження. Проведене дослідження дозволило отримати такі результати:

- визначено, що маркетинговий механізм може бути використаний як дієвий інструмент вирішення актуальних проблем суспільства, позначених у принципах сталого розвитку; 
- узагальнено наукові розробки, що довели можливість розгляду маркетингового механізму як відкритої систему із наявністю входу, виходу та внутрішньої структури;

- на основі запропонованого автором визначення поняття «маркетинговий механізм» обгрунтовано зазначення низки елементів маркетингового механізму (суб'єкти маркетингу, взаємозв'язки між ними, важелі впливу, об'єкт впливу, наявність якого обумовлена цільовою метою, суб'єкт, що керує станом маркетингового механізму та забезпечує його стійкість);

- доведено, що специфіка застосованих інструментів суб'єктами маркетингу обумовлює маркетингову природу механізму;

- визначено, що важливим елементом маркетингового механізму, що обумовлює доцільність його функціонування, виправданість перетворення об'єкту впливу та застосування відповідних важелів суб'єктами маркетингу, $є$ наявність та характер цільової мети (очікуваного результату);

- доведено доцільність свідомого створення дієвого маркетингового механізму управління соціально-значущими сферами 3 метою запобігання виникненню спонтанних механізмів, корегування функціонування якого буде ускладнене у майбутньому.

Отримані результати дозволяють сформувати напрямки подальшого наукового пошуку, спрямованого та визначення принципів та закономірностей функціонування маркетингового механізму на основі розуміння його структури задля формування наукового підгрунтя застосування його потенціалу для вирішення важливих проблем суспільства.

\section{Перелік посилань}

1. Квасницька Р. С., Джерелейко С. О. Організаційно-економічний механізм забезпечення бюджетування діяльності промислових підприємств України. Вісник ХмНУ. 2012. №5 т.1. С.66-70.

2. Смирнов С. О., Гільорме Т. В. Методологічна платформа формування організаційно-інформаційного механізму маркетингового просування енергозберігаючих технологій. Бізнес-інформ. 2015. №7. С. 311-315.

3. Гуляев В. В. Социальные механизмы предупреждения и разрешения социально-трудових конфликтов: Дис. ... канд. соц. наук. К., 2004.

4. Ілляшенко С. М. Маркетинг. Менеджмент. Інновації: монографія. Суми: ТОВ «Друкарський дім «Папірус», 2010. 621 с.

5. Рудницький С. Категорія «механізм» у суспільних науках. Украӥнський науковий журнал «Освіта регіону». 2011. №4. С. 111-121.

6. Заславская Т. И., Рывкина Р. В. Экономическая социология: исторические предпосылки и объект изучения. Экономическая соииология перестройка. М.: Прогресс. 1989. С. 30-44.

7. Дороніна М. С. Управління економічними та соціальними процесами підприємства: монографія. Харків: ХДЕУ, 2002. 431с.

8. Колодій А. М., Олійник А. Ю. Права людини і громадянина в Україні: навч. посібник. К.: Юрінком Інтер, 2003. 336 с. 
9. Старостіна А. О. Маркетингові дослідження. Практичний аспект: навч. посібник. К.: «Вільямс», 2000. 262 с.

10. Братенкова Т. М. Маркетинговый механизм устойчивого развития особо охраняемых природных территорий. Труды БГТУ: Экономика $u$ управление. 2014. №7. С. 241-245.

11. Курбацька Л. М., Ільченко Т. В., Кожушко І. Г. Маркетинговий механізм забезпечення конкурентоспроможності продовольчого ринку. Агросвіт. 2009. №15. С. 20-23.

\section{References}

1. Kvasnytska P. C. (2012), Organizational and economic mechanism of budgeting of industrial enterprises of Ukraine [Orhanizatsiino-ekonomichnyi mekhanizm zabezpechennia biudzhetuvannia diialnosti promyslovykh pidpryiemstv Ukrainy], Bulletin of KhNNU, No. 5 (1), P. 66-70.

2. Smyrnov S. O., Hilorme T. V. (2015), Methodological platform for the formation of organizational and information mechanism of marketing promotion of energy-saving technologies [Metodolohichna platforma formuvannia orhanizatsiinoinformatsiinoho mekhanizmu marketynhovoho prosuvannia enerhozberihaiuchykh tekhnolohii], Biznes-inform, No. 7, P.311-315.

3. Huliaev V. V. (2004), Social mechanisms for the prevention and resolution of social and labor conflicts [Sotsyalny mekhanyzmi preduprezhdeniia i razresheniia sotsyalno-trudovikh konfliktov], Dys. ... kand. sots. nauk.

4. Illiashenko S. M. (2010), Marketing. Management. Innovation: monograph [Marketynh. Menedzhment. Innovatsii: monohrafiia], Sumy: TOV «Drukarskyi dim «Papirus», P. 621.

5. Rudnytskyi S. (2011), The category of "mechanism" in the social sciences [Katehoriia «mekhanizm» u suspilnykh naukakh], Ukrainian scientific journal «Education of the region», No. 4, P. 111-121.

6. Zaslavskaya T. I., Ryvkina R. V. (1989), Economic sociology: historical background and object of study [Ekonomicheskaya sotsiologiya: istoricheskie predposylki i ob'ekt izucheniya], Moscow: Progress, P. 324.

7. Doronina M. S. (2002), Management of economic and social processes of the enterprise: monograph [Upravlinnia ekonomichnymy ta sotsialnymy protsesamy pidpryiemstva: monohrafiia], Kharkiv: KhDEU, P. 431.

8. Kolodii A. M., Oliinyk A. Yu. (2003), Human and citizen rights in Ukraine: educ. manual [Prava liudyny i hromadianyna v Ukraini: navch. posibnyk], Yurinkom Inter, P. 336.

9. Starostina A. O. (2000), Marketing researches. Practical aspect [Marketynhovi doslidzhennia. Praktychnyi aspekt], Viliiams, P. 262.

10. Bratenkova T. M. (2014), Marketing mechanism for the sustainable development of specially protected natural areas [Marketingovyy mekhanizm ustoychivogo razvitiya osobo okhranyaemykh prirodnykh territoriy], Trudy BGTU: Ekonomika i upravlenie, No. 7, P. 241-245.

11. Kurbatska L. M., Ilchenko T. V., Kozhushko I. H. (2009), Marketing mechanism of for ensuring the competitiveness of the food market [Marketynhovyi 
mekhanizm zabezpechennia konkurentospromozhnosti prodovolchoho rynku], Ahrosvit, No. 15, P. 20-23.

\section{РЕФЕРАТИ РЕФЕРАТЫ ABSTRACTS}

\section{УДК 339.138; JEL Classification: M380}

Коноваленко А. С. ЕЛЕМЕНТИ МАРКЕТИНГОВОГО МЕХАНІЗМУ

Mema. Метою статті є визначення ключових елементів маркетингового механізму шляхом узагальнення наукових підходів та поглядів дослідників на структуру маркетингового механізму на основі контент-аналізу наукових робіт. Методика дослідження. Метод контент-аналізу використано для систематизації існуючих підходів у науковій літературі до визначення ключових елементів маркетингового механізму як системи. Метод порівняння застосовано для встановлення подібних та відмінних поглядів науковців на визначення характерних елементів маркетингового механізму. Метод узагальнення застосовано для обгрунтування результатів дослідження. Методи аналізу і синтезу використано при визначенні окремих складових елементів маркетингового механізму та розгляду їх у єдності. Результати. В ході дослідження отримано результати: визначено, що маркетинговий механізм може бути використаний як дієвий інструмент вирішення актуальних проблем суспільства; доведено можливість розгляду маркетингового механізму як відкритої систему із наявністю входу, виходу та внутрішньої структури; визначено елементи маркетингового механізму; доведено, що маркетингову природу механізму визначають застосовані інструменти суб'єктів маркетингу, наявність та характер цільової мети; доведено доцільність свідомого створення дієвого маркетингового механізму управління соціально-значущими сферами 3 метою запобігання виникненню спонтанних механізмів. Наукова новизна. Уперше обгрунтовано підхід до визначення ключових елементів маркетингового механізму, що на відміну від існуючих підходів передбачає визначення характеру цільової мети (очікуваного результату), що дозволяє чітко окреслити доцільність функціонування маркетингового механізму у різних сферах, цілеспрямованість перетворення об'єкту впливу та застосування відповідних важелів суб'єктами маркетингу. Практична значущість. Визначення елементів маркетингового механізму формує наукове підгрунтя для розуміння принципів та закономірностей застосування маркетингового механізму для вирішення широкого кола проблем суспільства, зазначених у принципах сталого розвитку, застосуванні з метою підвищення ефективності маркетингової діяльності підприємств та використання у соціальній сфері.

Ключові слова: маркетинг; маркетинговий механізм; елементи; система; маркетингові інструменти; важелі впливу; суб’єкти маркетингу. 


\section{УДК 339.138; JEL Classification: M380}

\section{Коноваленко А. С. ЭЛЕМЕНТЫ МАРКЕТИНГОВОГО}

\section{МЕХАНИЗМА}

Цель. Целью статьи является определение ключевых элементов маркетингового механизма путем обобщения научных подходов к анализу структуры маркетингового механизма на основе контент-анализа научных работ. Методика исследования. Метод контент-анализа использован для систематизации существующих подходов в научной литературе к определению ключевых элементов маркетингового механизма как системы. Метод сравнения использован для выявления схожих и различных взглядов исследователей на определение характерных элементов маркетингового механизма. Метод обобщения использован для обоснования результатов исследования. Методы анализа и синтеза применены для определения отдельных структурных маркетингового механизма и рассмотрения их в единстве. Результаты. В ходе исследования получены результаты: определено, что маркетинговый механизм может использоваться как действенный инструмент решения актуальных проблем общества; доказана возможность рассмотрения маркетингового механизма как открытой системы с наличием входа, выхода и внутренней структуры; определены элементы маркетингового механизма; доказано, что маркетинговую природу механизма определяют используемые инструменты субъектов маркетинга, наличие и характер целевого результата; обоснована целесообразность сознательного создания действенного маркетингового механизма управления социально-значимыми сферами с целью предотвращения возникновения спонтанных механизмов. Научная новизна. Впервые обоснован подход к определению ключевых элементов маркетингового механизма, который в отличие от существующих подходов предусматривает определение характера целевого результата, что позволяет очертить целесообразность функционирования маркетингового механизма в различных сферах, целесообразность преобразования объекта воздействия и применения соответствующих рычагов субъектами маркетинга.

Практична значимость. Определение элементов маркетингового механизма формирует научную основу для понимания принципов и закономерностей применения маркетингового механизма для решения широкого диапазона проблем общества, закрепленных принципами устойчивого развития, применения с целью повышения эффективности маркетинговой деятельности предприятий и использования в социальной cфepe.

Ключевые слова: маркетинг, маркетинговый механизм, элементы, система, инструменты маркетинга, рычаги воздействия, субъекты маркетинга.

\section{UDC 339.138; JEL Classification: M380}

\section{Konovalenko A. ELEMENTS OF THE MARKETING MECHANISM}

Purpose. The aim of the article is to identify the key elements of the marketing mechanism by summarizing scientific approaches to the analysis of the structure of the marketing mechanism based on the content analysis of scientific works. 
Methodology of research. The content analysis method was used to systematize the existing approaches in the scientific literature to determine the key elements of the marketing mechanism as a system. The comparison method was used to identify similar and different views of researchers on determining the characteristic elements of the marketing mechanism. The generalization method is used to substantiate the results of the study. Methods of analysis and synthesis are applied to determine the individual structural marketing mechanism and consider them in unity. Findings. In the course of the study, the results were obtained: it was determined that the marketing mechanism can be used as an effective tool for solving pressing problems of society; proved the possibility of considering the marketing mechanism as an open system with the presence of input, output and internal structure; elements of the marketing mechanism are identified; it is proved that the marketing nature of the mechanism is determined by the tools used by marketing entities, the presence and nature of the target result; the expediency of consciously creating an effective marketing mechanism for managing socially significant areas in order to prevent the occurrence of spontaneous mechanisms is substantiated. Originality. For the first time, an approach has been substantiated to determine the key elements of the marketing mechanism, which, unlike existing approaches, provides for determining the nature of the target result, which allows us to outline the expediency of the functioning of the marketing mechanism in various fields, the feasibility of transforming the object of influence and the use of appropriate levers by marketing entities. Practical value. The definition of the elements of the marketing mechanism forms the scientific basis for understanding the principles and patterns of applying the marketing mechanism to solve a wide range of problems of society, enshrined in the principles of sustainable development, application in order to increase the efficiency of marketing activities of enterprises and use in the social sphere.

Key words: marketing; marketing mechanism; elements; system; marketing tools; leverage; marketing entities.

\section{Відомості про авторів / Сведения об авторах / About the Authors}

Коноваленко Анастасія Сергіївна - кандидат економічних наук, доцент, Таврійський державний агротехнологічний університет імені Дмитра Моторного, доцент кафедри маркетингу, м. Мелітополь, Україна; e-mail: avmvpmailru@gmail.com; ORCID ID: https://orcid.org/0000-0001-9061-5989. Моб. 0979943364.

Коноваленко Анастасия Сергеевна - кандидат экономических наук, доцент, Таврический государственный агротехнологический университет имени Дмитрия Моторного, доцент кафедры маркетинга, г. Мелитополь, Украина

Konovalenko Anastasiia - Candidate of Sciences (Economics), Associate Professor, D.Motorny Tavriia State Agrotechnological University Associate Professor at the Departament of Marketing, Melitopol, Ukraine 